\section{Elevated Microsprinklers Improve Protection of Citrus Trees in an Advective Freeze}

\author{
Larry R. Parsons, T. Adair Wheaton', Nick D. Faryna ${ }^{2}$, and \\ John L. Jackson ${ }^{3}$ \\ Citrus Research and Education Center, University of Florida, Institute of \\ Food and Agricultural Sciences, 700 Experiment Station Road, Lake \\ Alfred, FL 33850
}

Additional index words. Citrus sinensis, frost protection, irrigation

\begin{abstract}
The severe advective freeze of 23-26 Dec. 1989 killed most nonprotected trees in Florida's northern citrus region. Minimum temperatures reached - 8.3C with $>43$ hours below freezing. Microsprinklers elevated to a height of 0.6 or $0.9 \mathrm{~m}$ and placed inside the canopy of young 'Hamlin' and navel orange trees [Citrus sinensis (L.) Osb.] provided excellent protection to heights well above $1 \mathrm{~m}$. Initial survival height of trees with emitters elevated to $0.9 \mathrm{~m}$ was higher than has been reported for microsprinklers at a conventional $0.2-\mathrm{m}$ height in earlier severe freezes. Trees rapidly approached prefreeze canopy size from regrowth of the protected scaffold branches. Six months after the freeze, trees protected by microsprinklers elevated to $0.6 \mathrm{~m}$ and delivering 26 or 47 liters·hour ${ }^{-1}$ had regrown to a height of 1.4 or $1.7 \mathrm{~m}$, respectively. Trees with microsprinklers at a height of $0.9 \mathrm{~m}$ and delivering 101 liters $^{-} \mathrm{hour}^{-1} \mathrm{had}^{-}$ regrown to a height of $2.5 \mathrm{~m}$. Trees with no microsprinkler irrigation were killed to the ground. Twelve months after the freeze, trees with elevated microsprinklers were still significantly taller and showed greater recovery than those with microsprinklers near the ground.
\end{abstract}

Microsprinkler irrigation is a form of lowvolume irrigation that is commonly used to conserve water while irrigating fruit trees. In addition to normal irrigation, microsprinklers can also provide some cold protection of young and mature trees in radiation frosts (Buchanan et al., 1982; Parsons et al., 1981, 1982a, 1982b). Microsprinklers have also protected the lower portion of young citrus trees in severe advective freezes with temperatures as low as -7.2 (Parsons and Wheaton, 1987) or -8.9C (Davies et al., 1984). In windy freezes, young trees are usually protected to a height of $\approx 1 \mathrm{~m}$ (Parsons et al., 1985) and upper branches die. Since fruit yield is strongly correlated with tree size, any method that promotes greater canopy survival would lead to greater fruit production in the years following a freeze. Hence, there is great interest in protecting more of the tree, if possible, using microsprinkler irrigation.

Bourgeois and Adams (1987) used scaffold-branch irrigation to protect 1-year-old $1-m$-tall navel orange and satsuma mandarin (Citrus unshiu) trees. Average survival was $74 \%$ and $88 \%$ for orange and satsuma, respectively, under advective freeze conditions

Received for publication 2 Oct. 1990. Florida Agr. Expt. Sta. J. Series no. R-01067. The cost of publishing this paper was defrayed in part by the payment of page charges. Under postal regulations, this paper therefore must be hereby marked $a d$ vertisement solely to indicate this fact.

${ }^{1}$ Professor.

${ }^{2}$ Faryna Grove Care, Hwy 450, Umatilla, FL 32784 ${ }^{3}$ County Extension Agent, 30205 St. Rd. 19, Tavares, FL 32778
(-8.9C minimum). In this case, emitters were placed $\approx 0.75 \mathrm{~m}$ high and delivered 114 liters $\cdot \mathrm{h}^{-1}\left(24.6 \mathrm{~mm} \cdot \mathrm{h}^{-1}\right)$ on the wetted area.

Using several spray methods at various heights, Braud et al. (1981) showed that water could provide partial tree protection if applied continuously in a way that developed a self-supporting ice mass in the lower part of the canopy. Water applied overhead caused some limb breakage due to the weight of the ice mass that developed in the upper part of the canopy.

A major advective freeze occurred in Florida on 23-26 Dec. 1989. Minimum temperatures in the northern part of the citrus region reached $-8.3 \mathrm{C}$ or lower with $>43 \mathrm{~h}$ below 0C (Sells, 1990). This freeze had the longest durations below $0 \mathrm{C}$ of any freeze in 30 years (J.G. Georg, unpublished). Wind velocity commonly was $9 \mathrm{~m} \cdot \mathrm{sec}^{-1}$ or more. In the central ridge citrus area, numerous unprotected trees from the 28th parallel north were killed. Nevertheless, in several commercial orchards, trees with microsprinklers elevated within the canopy received less damage than nonirrigated trees or trees with microsprinklers placed close to the ground in adjacent blocks. We report that elevated microsprinklers provided greater freeze protection than has ever been reported before with microsprinklers and quantify tree recovery after the freeze.

Elevated microsprinklers in 20 commercial orchards near Umatilla, Fla., were effective in reducing freeze damage of 2- to 5year-old trees. Several sites of at least 200 trees each, representing a range of tree age and water application rates, were selected for this study. Measurements made on six trees at each site included height of microsprinkler, water volume and wetted area, initial tree height before the freeze, height of surviving wood 2 months after the freeze, and height of regrowth $\approx 6$ and 12 months after the freeze. Trees were navel or 'Hamlin' orange on sour orange $(C$. aurantium $\mathrm{L}$.) rootstock. Microsprinklers were elevated 0.6 or $0.9 \mathrm{~m}$ by placing the stake and sprinkler assembly on top of a polyvinyl chloride (PVC) support pipe (Fig. 1). The elevated microsprinkler was placed near the center of the canopy just north or west (upwind) of the trunk. The 4-mm (i.d.) water supply tubing was wrapped around the PVC support pipe so that ice loading on the tubing would not cause the stake assembly to fall over. Microsprinklers produced a $360^{\circ}$ continuous spray pattern with outputs of 101,47 , and 26 liters $\cdot \mathrm{h}^{-1}$ at sites 1,2 , and 3, respectively. Spray diameters ranged from 2.1 to $3.0 \mathrm{~m}$, which resulted in application rates on the wetted areas of 13.9 to $7.3 \mathrm{~mm} \cdot \mathrm{h}^{-1}$ for the three sites. Greater water volume, wetted area, and microsprinkler height were used for the larger 5-year-old trees at site 1.

Excellent protection was provided to the lower trunk and scaffold branches, with canopy protection extending above the height of the microsprinklers (Fig. 1). Although the top part of the canopy was killed, these trees nearly regained original size 6 months after the freeze due to rapid regrowth from the undamaged lower portion of the canopy.

The scaffold branches and a substantial portion of the canopy were protected at all three sites (Fig. 2). The February canopy height measurements indicated $55 \%$ to $70 \%$ of the canopy survived the freeze. Measurements made in June documented rapid regrowth, with canopy height returning to $70 \%$ to $85 \%$ of prefreeze dimensions. Twelve months after the freeze, tree height had surpassed the height before the freeze. Trees at site 1 were the largest ones among those at the three sites and had microsprinklers placed at a height of $0.9 \mathrm{~m}$ (Fig. 3, top). Tree height averaged $2.5 \mathrm{~m}$ after 6 months and $3 \mathrm{~m}$ after 12 months, indicating protection to more than twice the height previously reported with microsprinklers located near the soil surface (Parsons and Wheaton, 1987). Adjacent trees

Table 1. Characteristics of plots of orange trees studied.

\begin{tabular}{|c|c|c|c|c|}
\hline \multirow[b]{2}{*}{ Characteristic } & \multicolumn{4}{|c|}{ Site } \\
\hline & 4 & 5 & 6 & 7 \\
\hline Microsprinkler ht (m) & 0.6 & 0.15 & 0.6 & 0.03 \\
\hline Tree ht, Dec. $1990( \pm$ SD $)$ & $2.9 \pm 0.1$ & $2.4 \pm 0.3$ & $1.8 \pm 0.1$ & $1.4 \pm 0.2$ \\
\hline Trees lost (\%) & $<0.1$ & 20 & $<1.0$ & 10 \\
\hline Yield/tree (kg), Dec. 1990 & 51 & 0 & ... & -- \\
\hline
\end{tabular}

${ }^{2}$ For sites 4 and $5, \mathrm{n}=24$; for sites 6 and $7, \mathrm{n}=6$. 


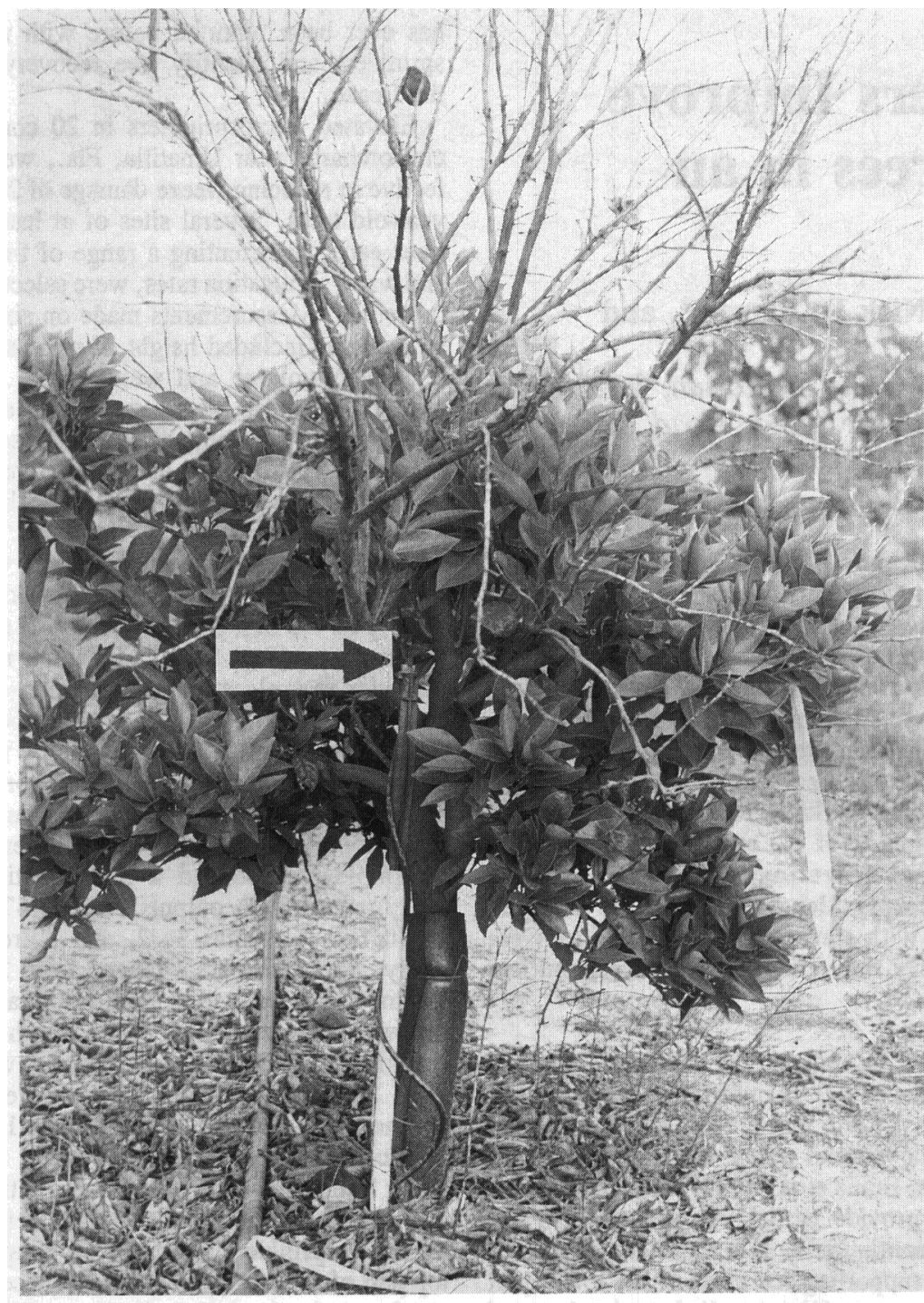

Fig. 1. Example of microsprinkler elevated to a height of $0.6 \mathrm{~m}$ inside the canopy of a 2-year-old citrus tree from site 2. Photo was taken on 28 Feb. 1990. Arrow indicates microsprinkler emitter. Note survival of the trunk and lower canopy as compared to the freeze-damaged upper canopy.

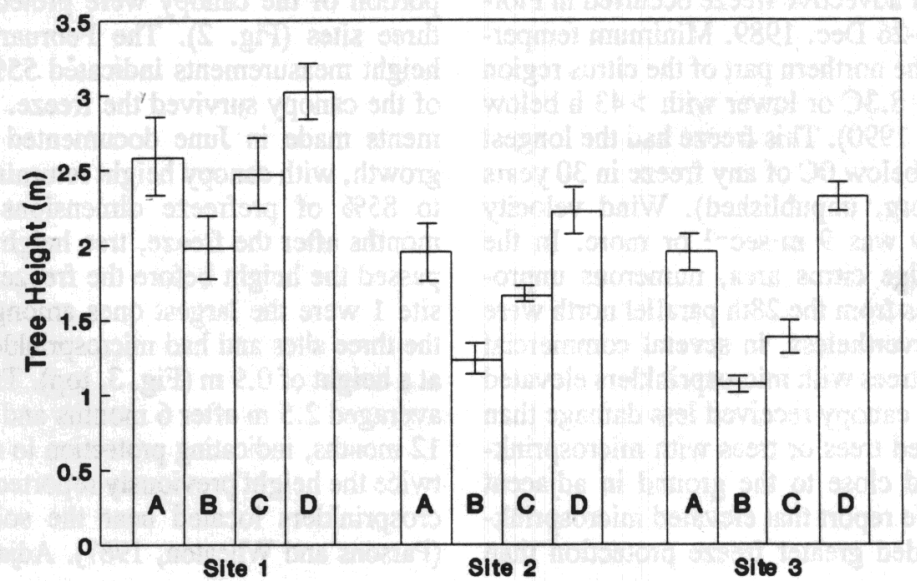

Fig. 2. Citrus tree heights before and after the 23-26 Dec. 1989 freeze. $A=$ height before freeze, $\mathrm{B}=$ survival height on 28 Feb. 1990, C = height on 11 June 1990, D = height on 6 Dec. 1990. Vertical bars indicate SD.

at site 1 received no water and were killed (Fig. 3, bottom).

Additional comparisons were made between elevated and traditionally located nonelevated microsprinklers at sites 4 through in Table 1. Sites 4 and 5 were adjacent to each other and within $3 \mathrm{~km}$ of sites 1-3. Sites 6 and 7 were within $1 \mathrm{~km}$ of each other and $33 \mathrm{~km}$ south of sites 1-5. A $t$ test was used to compare tree height between sites 4 and 5 and sites 6 and 7. In both cases, trees with elevated microsprinklers (sites 4 and 6) were significantly taller $(P=0.001)$ than trees with nonelevated microsprinklers. The percentage of trees lost due to the freeze was greater with the nonelevated microsprinklers (sites 5 and 7). Average fruit yield was 51 $\mathrm{kg} / \mathrm{tree}$ at site 4 one year after this severe freeze, while there was no fruit production at site 5 .

This study shows that protection can be obtained with older trees and to a greater height than was observed by Bourgeois and Adams (1987) in Louisiana. Our results confirm the benefits of elevating the microsprinkler reported in their Louisiana study and show that these results can apply to 2.6$\mathrm{m}$-tall trees in a severe advective freeze under Florida conditions. The application rate of $24.6 \mathrm{~mm} \cdot \mathrm{h}^{-1}$ to the wetted area, as used in the Louisiana study, is much higher than normally used for citrus irrigation systems in Florida. Application rates in the present study ranged from 7.3 to $13.9 \mathrm{~mm} \cdot \mathrm{h}^{-1}$, indicating freeze protection can be achieved at lower application rates.

As height of the microsprinkler is increased, the risk of limb breakage due to ice loading in the upper canopy increases. Since little or no limb breakage was observed in this study, we assume that trunk and scaffold limb diameters were sufficient to support the weight of the ice that developed. Elevated microsprinklers used in a mild freeze in Feb. 1991 caused some limb breakage in younger trees with thinner branches.

In addition to possible limb breakage, water applied over the tops of trees at insufficient precipitation rates can enhance cooling by evaporation. Mature Florida citrus trees were killed in a Dec. 1962 advective freeze by evaporative cooling with overhead sprinklers that applied water at $\approx 2.6 \mathrm{~mm} \cdot \mathrm{h}^{-1}$ (Gerber and Martsolf, 1965).

Several irrigation models predict application rates for freeze protection under windy conditions. For conditions encountered in this freeze $\left(-8.3 \mathrm{C}\right.$ minimum, $8.9 \mathrm{~m} \cdot \mathrm{sec}^{-1}$ windspeed), the Gerber and Harrison (1964) model and the SPAR 79 model (Perry et al., 1982) predict that 26.2 and $15.2 \mathrm{~mm} \cdot \mathrm{h}^{-1}$, respectively, would be needed for adequate protection. Our study shows that average precipitation rates ranging from 7.3 to 13.9 $\mathrm{mm} \cdot \mathrm{h}^{-1}$ on the wetted area were sufficient to protect young trees under these severe conditions. Hence, application rates in this study correspond more closely with the SPAR 79 model.

In the past, most successful protection of young trees has involved use of microsprinklers with $90^{\circ}$ or $180^{\circ}$ spray patterns (Davies et al., 1984; Parsons and Wheaton, 1987). Emitters such as these typically have average application rates of 6 to $19 \mathrm{~mm} \cdot \mathrm{h}^{-1}$ on the wetted area. Hence, application rates in this present study were similar to rates found ad- 

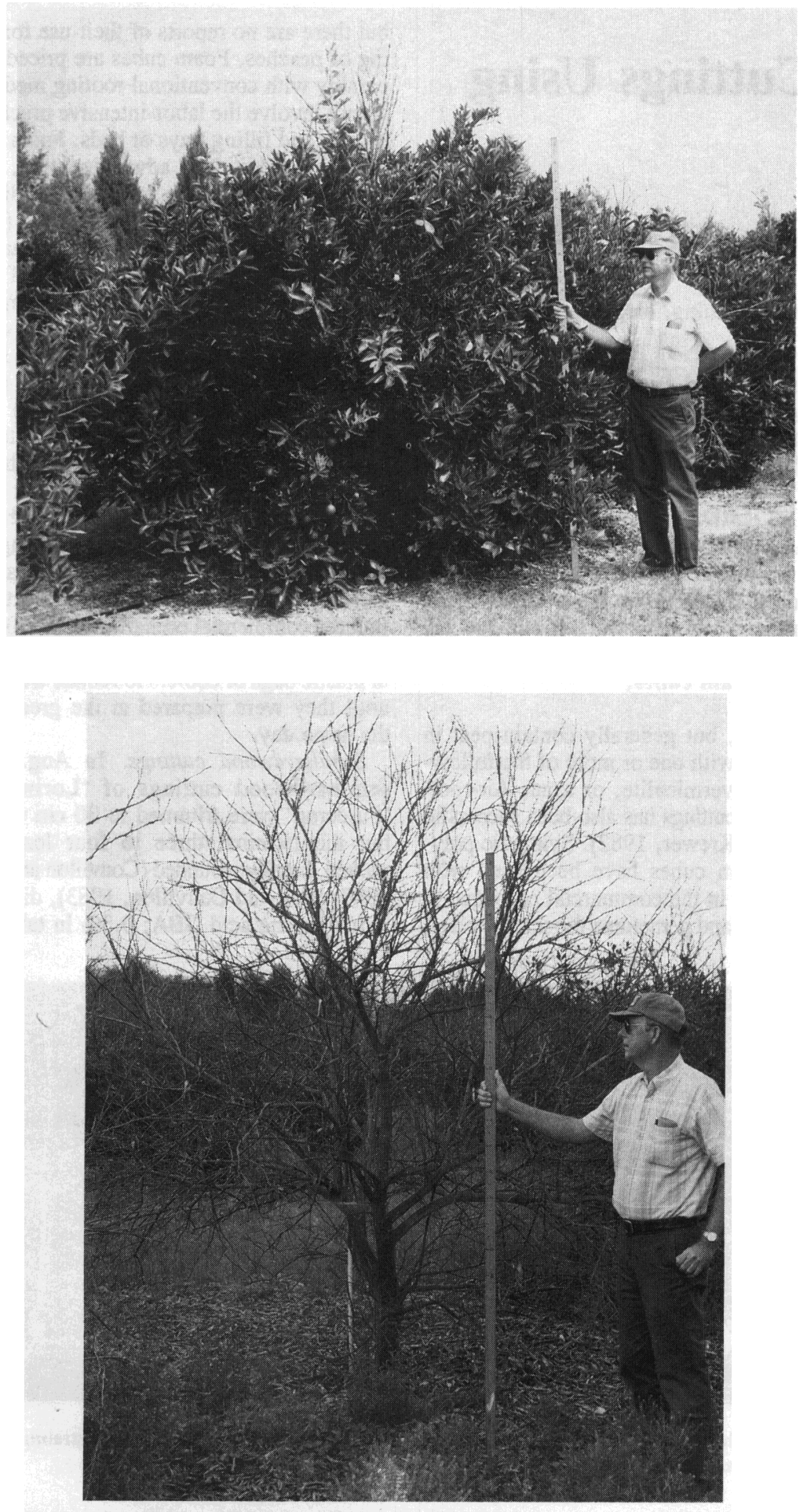

Fig. 3. (top) Example of citrus tree recovery at site 1 on 11 June 1990 after severe freeze on 23-26 Dec. 1989. Microsprinkler was elevated inside tree canopy to a height of $0.9 \mathrm{~m}$. Height of pole is $2.44 \mathrm{~m}$. (bottom) Example of dead citrus tree at site 1 following freeze. Microsprinkler was plugged, and this tree received no irrigation during the Dec. 1989 freeze.

equate in previous studies. Because water intercepted by upper branches can run down to lower branches before it completely freezes, we hypothesize that the application rate on lower branches may be higher than that on the overall microsprinkler-wetted area. Hence, the average application rate on the scaffold branches was sufficient to keep them alive.

With 1- or 2-year-old trees, one can protect to a height of $\approx 1 \mathrm{~m}$ with an emitter on the ground that sprays water upward into the canopy (Parsons and Wheaton, 1987). The major point of this study is to illustrate that an elevated emitter can protect trees to a significantly greater height than can an emitter placed near the ground. The sites in this study represent several commercial citrus orchards where this method was used successfully during a freeze. Since fruit yield is strongly correlated with tree size, a method such as this that protects more of the tree can result in a quicker resumption of fruit production after a serious freeze.

\section{Literature Cited}

Bourgeois, W.J. and A.J. Adams. 1987. Lowvolume scaffold branch irrigation for citrus freeze protection. HortScience 22:48-50.

Braud, H.J., P. Davidson, and P.L. Hawthorne. 1981. Reduction of freeze loss in citrus with water spray. Trans. Amer. Soc. Agr. Eng. 24:396-400.

Buchanan, D.W., F.S. Davies, and D.S. Harrison. 1982. High and low volume undertree irrigation for citrus cold protection. Proc. Fla. State Hort. Soc. 95:23-26.

Davies, F.S., L.K. Jackson, and L.W. Rippetoe. 1984. Low volume irrigation and tree wraps for cold protection of young Hamlin orange trees. Proc. Fla. State Hort Soc. 97:25-27.

Gerber, J.F. and I.S. Harrison. 1964. Sprinkler irrigation for cold protection of citrus. Trans. Amer. Soc. Agr. Eng. 7:464-468.

Gerber, J.F. and J.D. Martsolf. 1965. Protecting citrus from cold damage. Univ. of Florida Circ. 287.

Parsons, L.R., B.S. Combs, and D.P.H. Tucker. 1985. Citrus freeze protection with microsprinkler irrigation during an advective freeze. HortScience 20:1078-1080.

Parsons, L.R. and T.A. Wheaton. 1987. Microsprinkler irrigation for freeze protection: Evap orative cooling and extent of protection in an advective freeze. J. Amer. Soc. Hort. Sci. 112:897-902.

Parsons, L.R., T.A. Wheaton, D.P.H. Tucker, and J.D. Whitney. 1982a. Low volume microsprinkler irrigation for citrus cold protection. Proc. Fla. State Hort. Soc. 95:20-23.

Parsons, L.R., T.A. Wheaton, and J.D. Whitney. 1981. Low volume microsprinkler undertree irrigation for frost protection of young citrus trees. Proc. Fla. State Hort. Soc. 94:55-59.

Parsons, L.R., T.A. Wheaton, and J.D. Whitney. 1982b. Undertree irrigation for cold protection with low-volume microsprinklers. HortScience 17:799-801.

Perry, K.B., C.T. Morrow, A.R. Jarrett, and J.D. Martsolf. 1982. Evaluation of sprinkler application rate models used in frost protection. HortScience 17:884-885.

Sells, C.D. 1990. A comparison of December freezes. Fruit Crops Fact Sheet. FC 84. Univ. of Florida Coop. Ext. Serv., Gainesville. 